\title{
FATE OF HELICOBACTER PYLORI ARTIFICIALLY INOCULATED IN LETTUCE AND CARROT SAMPLES
}

\author{
Bruna C. Gomes; Elaine C.P. De Martinis*
}

Departamento de Análises Clínicas, Toxicológicas e Bromatológicas, Faculdade de Ciências Farmacêuticas de Ribeirão Preto, Universidade de São Paulo, Ribeirão Preto, SP, Brasil.

Submitted: December 17, 2003; Approved: April 13, 2004.

\begin{abstract}
Helicobacter pylori is known, worldwide, as the causative agent of gastric diseases. However, its transmission route has not been completely understood. To evaluate the survival of $H$. pylori (a clinical and a reference strain) artificially inoculated on lettuce and carrot samples, portions of $25 \mathrm{~g}$ were inoculated with approximately $10^{6} \mathrm{CFU} / \mathrm{g}$ of $\mathrm{H}$. pylori and packed under normal and/or modified atmosphere (3\% oxygen, $10 \%$ carbon dioxide, and $87 \%$ nitrogen). The inoculated food samples were stored at $8^{\circ} \mathrm{C}$, with daily enumeration of $H$. pylori populations on Columbia blood agar (CBA) and/ or Helicobacter pylori Special Peptone Agar (HPSPA). When CBA with antibiotics was used, the clinical isolate $H$. pylori HP1 was detected for up to $72 \mathrm{~h}$ in sanitized lettuce and carrot. In sterilized carrot samples, H. pylori HP1 remained viable for up to $96 \mathrm{~h}$. The CBA without antibiotics allowed the recovery of $H$. pylori ATCC 43629, from carrot samples stored in both atmospheres tested, for up to 120 hours. Our results reinforce that foodborne transmission of $H$. pylori cannot be disregarded yet.
\end{abstract}

Key words: $H$. pylori, peptic ulcer, modified atmosphere, vegetable

\section{INTRODUCTION}

Helicobacter pylori is a bacterium that is able to colonize the human gastric mucosa and plays an important role in chronic gastritis, gastric/duodenal ulceration and maybe cancer (7). Despite the clinical significance of the diseases caused by $H$. pylori, the transmission routes are not completely understood $(8,17,20,21)$. To date, iatrogenic, oral-oral, and fecal-oral routes are the main postulated modes of transmission. The existence of the fecal-oral route depends partially on the ability of $H$. pylori to survive at least for a limited time in the environment $(11,13)$.

When H. pylori is exposed to adverse conditions, its morphology changes from rod shaped viable cells to viable but non-cultivable cocci (VNC). However, the coccoid form is believed to be still infective $(4,6)$.

West et al. (23) demonstrated that in the VNC state, H. pylori was able to survive in water microcosms for up to one year.
Successful cultivation of $H$. pylori from wastewater stresses the hypothesis that poor quality water could represent an important vehicle for its transmission $(1,11,15,16)$. Epidemiological surveys revealed a positive correlation between infection by $H$. pylori and the consumption of poor hygienic quality water and foods $(1,2,9,10)$. These findings are of special concern for populations with high $H$. pylori prevalence, and are deprived of basic sanitation systems.

Moreover, nowadays it has been observed an increasing demand for minimally processed vegetables packed under modified atmosphere (3). It can be speculated that this kind of packaging will favour the survival of pathogens requiring reduced oxygen concentration for its growth, as is the case of H. pylori.

Difficulties in elucidating the transmission routes of $H$. pylori are partially due to unsuitable detection methods available for the recovery of this pathogen from samples with a dense competing microflora $(14,17,18)$. In this work we evaluated

*Corresponding author. Mailing address: Departamento de Análises Clínicas, Toxicológicas e Bromatológicas, FCFRP-USP, Av. do Café s/n. 14040903, Ribeirão Preto, SP, Brasil. Tel.: (+5516) 6024267. Fax: (+5516) 6331936. E-mail: edemarti@usp.br 
selective and non-selective media for the recovery of $H$. pylori from vegetable foods.

\section{MATERIALS AND METHODS}

\section{Bacterial strains}

A clinical isolate of H. pylori (designated as H. pylori HP1) and $H$. pylori ATCC 43629 were used in this study. The former was isolated from human gastric biopsy at Faculdade de Medicina de Ribeirão Preto - Universidade de São Paulo, Brazil and was kindly donated by Prof. Marcelo Brocchi. The reference strain was obtained directly from American Type Culture Collection (ATCC), USA. The bacterial strains were kept at $70^{\circ} \mathrm{C}$ in tubes containing $0.8 \mathrm{ml}$ of Brain Heart Infusion broth (Oxoid, Ltd., Basingstoke, England) with 20\% (v/v) glycerol (Merck, KgaA, Darmstadt, Germany). Working cultures were made right before each use.

\section{Inoculum preparation}

The content of $H$. pylori stock culture vial was spread on the surface of a Columbia Agar plate supplemented with 5\% defibrinated horse blood (CBA) and selective supplement for H. pylori, according to Kelly et al. (14). The selective supplement contained: $10 \mathrm{mg} / \mathrm{l}$ vancomycin, $5 \mathrm{mg} / \mathrm{l}$ trimethroprim lactate, 5 $\mathrm{mg} / \mathrm{l}$ cefsulodin and $5 \mathrm{mg} / \mathrm{l}$ amphotericin B (Dent - Oxoid). This medium was named in the present work as modified Columbia Agar. Plates were incubated at $37^{\circ} \mathrm{C}$ using an anaerobic jar with a microaerobic atmosphere generator sachet (CampyGen Oxoid).

A three-day-old culture of $H$. pylori on agar plate was washed with $4 \mathrm{ml}$ of sterile saline $(0.85 \%$ w/v sodium chloride) to yield a suspension of cells. This suspension was further transferred to a sterile test tube and serial decimal dilutions were prepared. The optical density at $620 \mathrm{~nm}$ (spectrophotometer Spectronic 20, Bausch \& Lomb, Kyoto, Japan) was obtained for each dilution and the number of $\mathrm{CFU} / \mathrm{ml}$ was determined by spread plating $0.1 \mathrm{ml}$ of each dilution on CBA and incubating for $24 \mathrm{~h}$ at $37^{\circ} \mathrm{C}$, under microaerophilic atmosphere. H. pylori used in inoculation experiments was subjected to additional tests such as: urease, catalase, oxidase and Gram staining.

\section{Food samples}

Lettuce (Lactuca sativa) and carrot (Daucus carota) samples were purchased at a retail market in the city of Ribeirão Preto São Paulo, Brazil, and transported to laboratory under refrigeration.

\section{Lettuce samples}

Upon arrival, the lettuce sample was hand washed under tap water, sanitized by dipping in a sodium hypochlorite solution $(100 \mathrm{mg} / \mathrm{l})$, rinsed and fractionated into $25 \mathrm{~g}$ portions. Subsequently, the fractionated sample was exposed to U.V. radiation $(\lambda=253.7 \mathrm{~nm})$ for $30 \mathrm{~min}$ on each side, in a safety cabinet hood (level II). The residual mesophilic microflora was enumerated by plating $0.1 \mathrm{ml}$ of decimal dilutions of sample prepared in sterile saline ( $0.85 \% \mathrm{w} / \mathrm{v}$ sodium chloride) on Plate Count Agar (Oxoid). The plates were incubated at $37^{\circ} \mathrm{C}$ for $24 \mathrm{~h}$. A control that was only washed (not sanitized) was also analyzed.

\section{Carrot samples}

The carrot samples were hand washed under tap water, peeled and fractionated in to $25 \mathrm{~g}$ portions. For decontamination, we applied the same treatment used for lettuce samples. Moreover, portions of carrot sample were decontaminated by sterilization in an autoclave at $121^{\circ} \mathrm{C}$ for $15 \mathrm{~min}$, to eliminate the interference of autochthonous microflora in selective media.

\section{Artificial inoculation}

Portions (25g) of carrot and lettuce samples were individually packed in plastic bags and inoculated with $2.5 \mathrm{ml}$ of $H$. pylori $10^{-1}$ dilution (prepared as described above) to yield a final population of ca. $10^{6}-10^{7} \mathrm{CFU} / \mathrm{g}$. Uninoculated samples were used as control. The bags containing inoculated and control samples were stored at $8^{\circ} \mathrm{C}$ until the enumeration time.

Additionally, we tested the survival time of $H$. pylori ATCC 43629 artificially inoculated in sterilized carrot sample packaged in plastic bags with high barrier to oxygen (Cryovac ${ }^{\circledR}$, São Paulo, Brazil), filled with a microaerophilic gas mixture comprising 3\% $\mathrm{O}_{2}, 10 \% \mathrm{CO}_{2}$, and $87 \% \mathrm{~N}_{2}$ (Air liquide, São Paulo, Brazil) using Selovac 200B (Selovac, São Paulo, Brazil). Uninoculated samples were used as controls. The inoculated and control samples were stored at $8^{\circ} \mathrm{C}$ until the enumeration time.

\section{Evaluation of $\boldsymbol{H}$. pylori survival}

\section{Culture media}

H. pylori HP1 was recovered in modified CBA, and $H$. pylori ATCC 43629 in CBA and in HPSPA (Helicobacter pylori Special Peptone Agar) supplemented with vancomycin (10 mg/l), amphotericin $(5 \mathrm{mg} / \mathrm{l})$, cefsulodin $(10 \mathrm{mg} / \mathrm{l})$, polymyxin B sulfate $(62,000 \mathrm{IU} / \mathrm{l})$, trimethoprim $(40 \mathrm{mg} / \mathrm{l})$ and sulfamethoxazole $(20$ $\mathrm{mg} / \mathrm{l})(14,18)$. HPSPA and Columbia agar without supplements were also tested for the recovery of $H$. pylori ATCC.

\section{Sampling procedure}

For the recovery of $H$. pylori $\mathrm{HP} 1$ from artificially inoculated lettuce and carrot samples, two bags of each inoculated samples and the control bag were added of $225 \mathrm{ml}$ of saline and homogenized for $1 \mathrm{~min}$, using a Bag Mixer (Interscience, France). Serial decimal dilutions were prepared and each dilution $(0.1 \mathrm{ml})$ was spread plated on modified CBA. The plates were incubated at $37^{\circ} \mathrm{C}$ in anaerobic jars with microaerophilic atmosphere generator sachet (CampyGen, Oxoid). This procedure was 
repeated until the population of $H$. pylori decreased to levels below the detection limit of the method.

The same protocol was followed for the recovery of $H$. pylori ATCC 43629 artificially inoculated in carrot samples. Besides modified CBA, we also used CBA and HPSPA (Helicobacter pylori Special Peptone Agar) without antibiotics and HPSPA supplemented with vancomycin $(10 \mathrm{mg} / \mathrm{l})$, amphotericin $(5 \mathrm{mg} / \mathrm{l})$, cefsulodin $(10 \mathrm{mg} / \mathrm{l})$, polymyxin B sulfate $(62,000 \mathrm{IU} / \mathrm{l})$, trimethoprim $(40 \mathrm{mg} / \mathrm{l})$ and sulfamethoxazole $(20 \mathrm{mg} / \mathrm{l})$.

\section{RESULTS}

The characterization tests of the $H$. pylori inocula revealed presence of catalase positive, oxidase positive, urease positive and Gram negative rods. The same profile was found for the viable cells of $H$. pylori recovered along all the experiments. $H$. pylori was not detected in any uninoculated samples.

Fig. 1 represents the survival curve of $H$. pylori HP1 in lettuce and carrot samples. At day zero, the population in carrot samples was $1.4 \times 10^{7} \mathrm{CFU} / \mathrm{g}$ and was reduced to $5.2 \times 10^{6} \mathrm{CFU} / \mathrm{g}$ after $24 \mathrm{~h}$. The number of viable $H$. pylori cells steadily decreased in the following days and at $120 \mathrm{~h}$, it was undetectable (Fig. 1).

When non-sterile carrot was used for inoculation studies, H. pylori HP1 remained viable for up to $72 \mathrm{~h}$ (Fig. 1). In lettuce

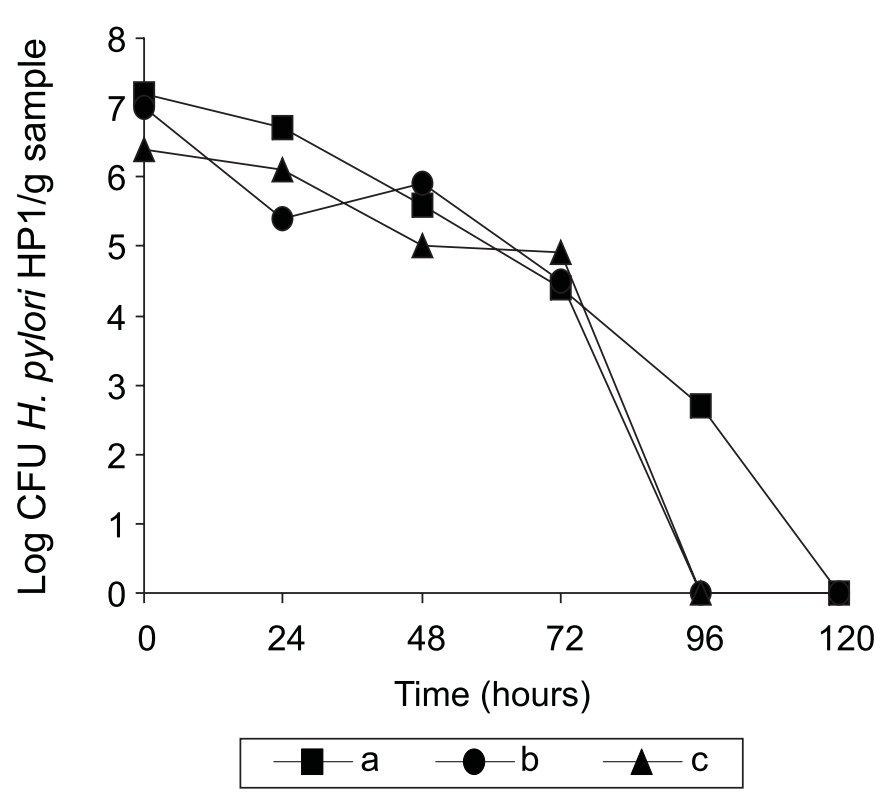

Figure 1. Survival curve of $H$. pylori HP1, artificially inoculated in carrot and lettuce samples stored at $8^{\circ} \mathrm{C}$, enumerated on modified Columbia Agar and incubated at $37^{\circ} \mathrm{C}$. a: sterilized carrot sample; b: carrot sample sanitized with $100 \mathrm{mg}$ chlorine/l and exposure to UV radiation for $30 \mathrm{~min}$ per side; c: lettuce sample sanitized with $100 \mathrm{mg}$ chlorine/l and exposure to UV radiation for $30 \mathrm{~min}$ per side. samples, a survival time of $72 \mathrm{~h}$ was also observed for $H$. pylori HP1. After this time, the background microflora overgrew $H$. pylori, preventing its detection. It is also possible that $H$. pylori cells converted to VNC state.

H. pylori ATCC 43629 did not grow on Columbia blood agar or on HPSPA supplemented with antibiotics at any time evaluated. Hence, we carried out further studies with $H$. pylori ATCC 43629 using culture media without selective supplements and sterilized carrot samples.

Fig. 2 shows the survival curve of $H$. pylori ATCC 43629 in sterilized carrot samples packaged under normal and modified atmospheres and stored at $8^{\circ} \mathrm{C}$, using Columbia blood agar supplemented with 5\% horse blood. H. pylori ATCC 43629 cells were recovered for up to 120 hours from samples stored under both atmospheres. At the end of the experiments $H$. pylori counts decreased 1.0 and $1.1 \log$ in the samples packaged, under normal or modified atmosphere, respectively.

Different results were obtained when the recovery of $H$. pylori ATCC 43629 was done in HPSPA (Fig. 3). We obtained initial counts of $10^{3} \mathrm{CFU}$ of $H$. pylori per gram of carrot samples, and within 24 hours the counts dropped bellow the detection limit of the method for samples packaged under normal or modified atmosphere.

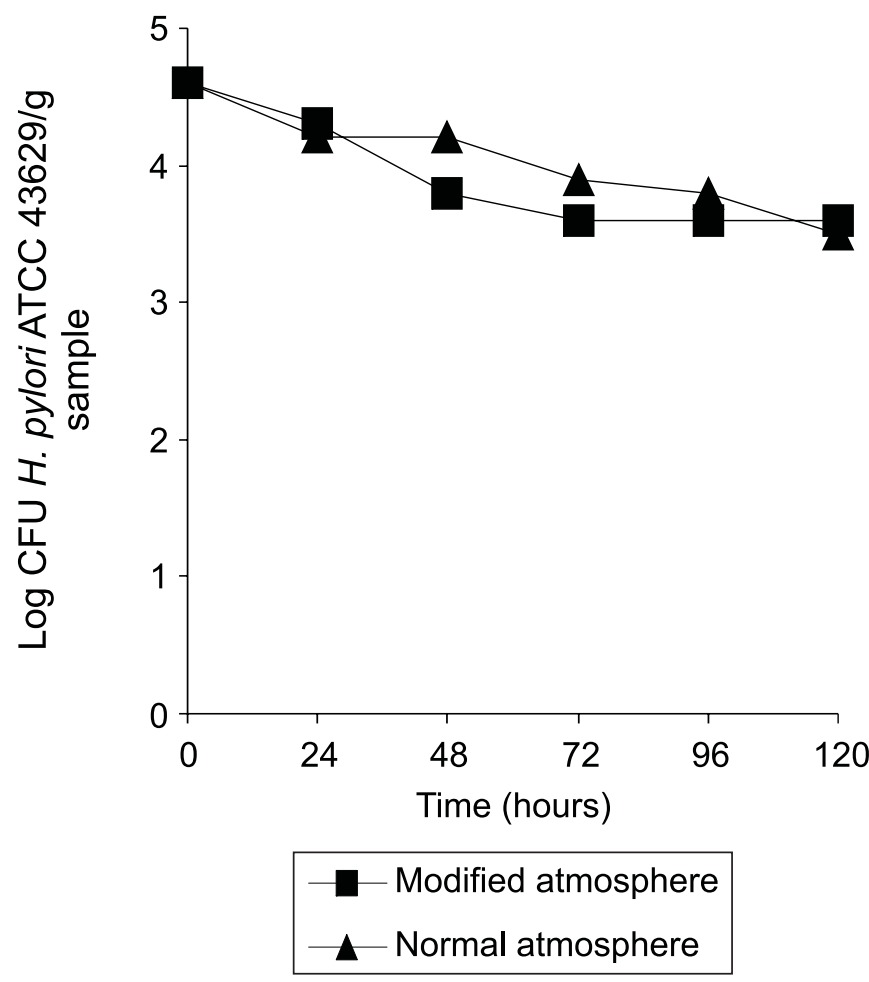

Figure 2. Survival curve of $H$. pylori ATCC 43629 artificially inoculated in sterilized carrot samples stored at $8^{\circ} \mathrm{C}$, enumerated on Columbia blood agar added $5 \%$ of horse blood. 


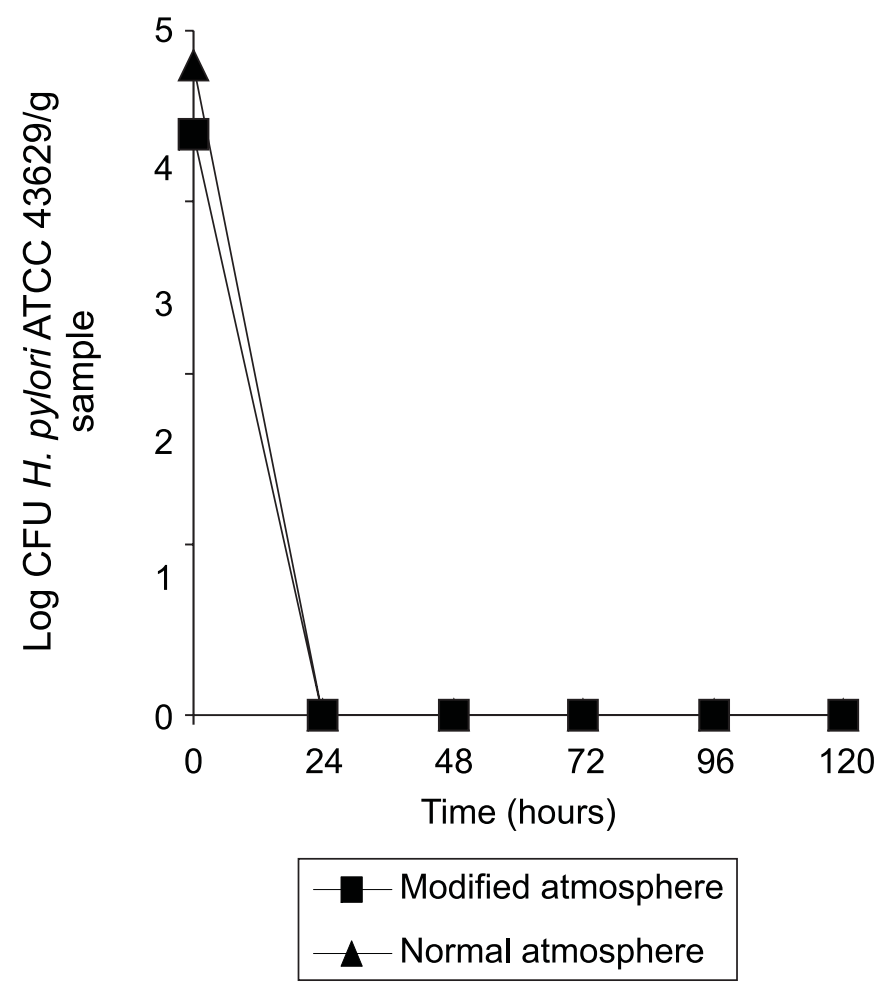

Figure 3. Survival curve of $H$. pylori ATCC 43629 artificially inoculated in sterilized carrot samples stored at $8^{\circ} \mathrm{C}$, enumerated on HPSPA without antibiotics.

\section{DISCUSSION}

Several agar media supplemented with horse blood and antibiotics have been employed for the isolation of $H$. pylori from gastric biopsies (22). In this work, modified Columbia agar allowed the detection of $H$. pylori HP1 cells artificially inoculated in selected vegetables. This is in agreement with the findings of Kelly et al. (14) who demonstrated the ability of modified Columbia agar to recover $H$. pylori from samples with faster growing autochthonous microorganisms.

H. pylori HP1 lost viability after initial experiments and the results shown are average of duplicates obtained with the same set of experiments. A survival time of $96 \mathrm{~h}$ was found for $H$. pylori $\mathrm{HP} 1$ in sterile carrot stored at $8^{\circ} \mathrm{C}$. According to Catrenich and Makin (5), the loss in detectability after a initial period of incubation could indicate the conversion of viable $H$. pylori cells to coccoid shape (VNC state).

When non-sterile carrot samples were analyzed, the survival time of H. pylori HP1 was shorter ( $72 \mathrm{~h}$ ). The colonies observed in plates at $96 \mathrm{~h}$ were atypical and were more likely constituents of the psychrotrophic background microflora. This microflora was not detectable in the beginning of the experiment due either to injury induced by the sanitizer or presence in very low numbers.
In agar plates prepared from lettuce samples, besides colonies with morphology typical of $H$. pylori, we also observed atypical ones, but viable $H$. pylori $\mathrm{HP} 1$ cells were recovered for up to $72 \mathrm{~h}$. This suggests that the sanitizing treatment was not effective for total inactivation of the background microflora, which impaired H. pylori HP1 growth and/or detection after 72 h. Poms and Tatini (17) recovered H. pylori NCTC 11638 artificially inoculated in lettuce samples, for up to $48 \mathrm{~h}$, using Wilkins-Chalgren agar as selective plating medium. Those authors hypothesized that the short survival time could be attributed to the faster growth of the background microflora, less susceptible to environmental stresses.

Jiang and Doyle (12) analyzed the survival of $H$. pylori in samples of ground beef. $H$. pylori could be recovered from irradiated ground beef, within 7 days using brain heart infusion broth with 7\% horse serum. However, they observed that this pathogen was not recovered from fresh ground beef, because indigenous bacteria outgrew the pathogen since the first 24 hours of experiment.

We observed that modified Columbia agar and HPSPA with antibiotics did not support the growth of H. pylori ATCC 43629 and the experiments with this strain had to be carried out with heat sterilized carrot using non-selective media. This could be attributed partially to the high level of genetic diversity presented by $H$. pylori strains, which may cause fail of growth in currently available defined media (19).

Growth of $H$. pylori is better achieved in a microaerophilic atmosphere, since elevated tension of oxygen could be toxic for its growth. So, we analyzed the effect of packaging under a modified atmosphere (very similar to that required for $H$. pylori growth) on the survival time of $H$. pylori ATCC 43629 in carrot samples. Our results (Fig. 2) showed that besides gaseous composition of the environment, other factors should have been decisive for $\mathrm{H}$. pylori survival, since similar results were observed for normal and modified atmosphere.

When the recovery of $H$. pylori ATCC 43629 was done in HPSPA without antibiotics, we observed that, since the first 24 hours, this microorganism lost its viability (Fig. 3). Testerman et al. (19) reported difficulties when cultivating $H$. pylori in culture media without blood or serum. The authors affirmed that, besides the classical nutritional requirements, blood components would offer other stimulating factors for $\mathrm{H}$. pylori growth.

Differences between the survival time of a clinical isolate of $H$. pylori and a reference strain were early reported. West et al. (24) obtained diverse results when they compared the effect of physical environmental conditions on the survival of a clinical isolate of $\mathrm{H}$. pylori and a reference strain. They affirmed that the difference could be due to repeated subculture, which would lead to a laboratory adaptation and possible in vitro chromosomal mutation. Another hypothesis was that $H$. pylori changed to VNC stage. 
The results for survival of $H$. pylori ATCC 43629 (Figs. 2 and 3) represent the average of two experiments. A third independent replicate was performed, but the results obtained for each condition in both culture media were unexpectedly different (data not shown).

Similar problems were reported by others researchers. West et al. (24) evaluated the effects of physical environment on survival of three strains of $H$. pylori and, reported a variability between repeated experiments in survival times of the same $H$. pylori strain. They affirmed that the variability was either of unknown cause or due to contamination of inocula. Considering that we did not detect contamination of inoculum, we hypothesize the difference we observed could be explained by genetic diversity of $H$. pylori or by its morphological conversion from bacillary to coccoid form.

Jiang and Doyle (12) also performed experiments with $H$. pylori aiming to optimize the detection in foods. The authors reported that, in one of the conditions tested, quite different results were obtained for a repetition of the same experiment.

In conclusion, the role of vegetables eaten raw in the transmission of $H$. pylori cannot be completely discarded, because $H$. pylori is able to survive in foods at least for a limited time. The choice of a culture medium to recover this pathogen from samples with a dense microflora still needs to be carefully studied to prevent underestimation of $\mathrm{H}$. pylori populations in food and environmental samples.

\section{ACKNOWLEDGEMENTS}

B.C. Gomes is grateful to CNPq - Conselho Nacional de Desenvolvimento Científico e Tecnológico (Brazilian National Research Council) for a master's fellowship, and to Cryovac ${ }^{\circledR}$ (São Paulo, Brazil) for kindly donating the plastic bags with high barrier to oxygen.

\section{RESUMO}

\section{Recuperação de Helicobacter pylori artificialmente inoculado em amostras de alface e cenoura}

H. pylori é o agente da maioria dos casos de gastrites e úlceras pépticas. Entretanto, sua forma de transmissão não foi completamente elucidada. Para avaliar a sobrevivência de $H$. pylori (uma cepa de referência e uma clínica), artificialmente inoculado em amostras de cenoura e alface, porções de $25 \mathrm{~g}$ das amostras receberam aproximadamente $10^{6} \mathrm{UFC} / \mathrm{g}$ de $H$. pylori, e foram embaladas em atmosfera normal e/ou modificada (3\% oxigênio, $10 \%$ dióxido de carbono, e $87 \%$ nitrogênio). Em seguida, foram armazenadas a $8^{\circ} \mathrm{C}$, com enumeração diária da população de $H$. pylori em ágar Columbia sangue (CBA) e/ou Helicobacter pylori Special Peptone Agar (HPSPA). Quando usamos CBA com antibióticos, o isolado clínico de $H$. pylori
(HP1) foi detectado por até 72 horas nas amostras de alface e cenoura sanitizadas. Em amostras de cenoura esterilizadas, $H$. pylori HP1 permaneceu viável por até 96 horas. CBA sem antibióticos permitiu a recuperação de H. pylori ATCC 43629, a partir de amostras de cenoura embaladas em ambas as atmosferas, por até 120 horas. Nossos resultados reforçam que a transmissão de H. pylori, através do consumo de água e alimento contaminados, ainda não pode ser descartado.

Palavras-chave: H. pylori, úlcera péptica, atmosfera modificada, vegetais

\section{REFERENCES}

1. Baker, K.H.; Hegarty, J.P. Presence of Helicobacter pylori in drinking water is associated with clinical infection. Scand. J. Infect. Dis., 33 744-746, 2001.

2. Begue, R.E.; Gonzales, J.L.; Correa-Gracian, H.; Tang, S.C. Dietary risk factors associated with the transmission of Helicobacter pylori in Lima, Peru. Am. J. Trop. Med. Hyg., 59: 637-640, 1998.

3. Beuchat, L.R. Ecological factors influencing survival and growth of human pathogens on raw fruits and vegetables. Microbes Infect, 4: 413-423, 2002.

4. Bode, G.; Mauch, F.; Malfertheiner, P. The coccoid forms of Helicobacter pylori. Criteria for their viability. Epidemiol. Infect. 111: 483-490, 1993.

5. Catrenich, C.E.; Makin, K.M. Characterization of the morphologic conversion of Helicobacter pylori from bacillary to coccoid forms. Scand. J. Gastroenterol. Suppl., 181: 58-64, 1991.

6. Donelli, G. et al. The effect of oxygen on the growth and cell morphology of Helicobacter pylori. FEMS Microbiol. Lett., 168: 9 15, 1998.

7. Dunn, B.E.; Cohen, H.; Blaser, M.J. Helicobacter pylori. Clin. Microbiol. Rev., 10: 720-741, 1997.

8. Gomes B.C.; De Martinis, E.C.P. The significance of H. pylori in water, food and environmental samples. Food Control., 15:397403, 2004.

9. Goodman, K.J. et al. Helicobacter pylori infection in the Colombia Andes: a population-based study of transmission pathways. Am. J. Epidemiol., 144: 290-299, 1996.

10. Hopkins, R.J. et al. Seroprevalence of Helicobacter pylori in Chile: vegetables may serve as one route of transmission. J. Infect. Dis., 168: 222-226, 1993.

11. Hulten, K. et al. Helicobacter pylori in drinking water in Peru. Gastroenterol., 110: 1031-1035, 1996.

12. Jiang, X.; Doyle, M.P. Optimizing enrichment culture conditions for detecting Helicobacter pylori in foods. J. Food Prot., 65: 1949 1954, 2002

13. Karim, Q.N.; Maxwell, R.H. Survival of Campylobacter pylori in artificially contaminated milk. J. Clin. Pathol., 42: 778, 1989.

14. Kelly, S.M.; Pitcher, M.C.L.; Farmery, S.M.; Gibson, G.R. Isolation of Helicobacter pylori from feces of patients with dyspepsia in the United Kingdom. Gastroenterology, 107: 1671-1674, 1994.

15. Klein, P.D.; Graham, D.Y.; Gaillour, A.; Opekun, A.R.; Smith, E. O'Brian. Water source as risk factor for Helicobacter pylori infection in Peruvian children. Lancet, 337: 1503-1506, 1991.

16. Park, S.R.; Mackay, W.G.; Reid, D.C. Helicobacter sp. recovered from drinking water biofilm sampled from a water distribution system. Wat. Res., 35: 1624-1626, 2001.

17. Poms, R.E.; Tatini, S.R. Survival of Helicobacter pylori in ready-toeat foods at $4^{\circ}$ C. Int. J. Food Microbiol., 63: 281-286, 2001. 
18. Stevenson, T.H.; Lucia, L.M.; Acuff, G.R. Development of a selective medium for isolation of Helicobacter pylori from cattle and beef samples. Appl. Environ. Microbiol., 66: 723-727, 2000.

19. Testerman, T.L.; McGee, D.J.; Mobley, H.L.T. Helicobacter pylori growth and urease detection in the chemically defined medium Ham's F-12 nutrient mixture. J. Clin. Microbiol., 39: 3842-3850, 2001.

20. Van Duynhoven, Y.T.; de Jonge, R. Transmission of Helicobacter pylori: a role for food? Bull. World Health Organ., 79: 455-460, 2001.

21. Velázquez, M.; Feirtag, J.M. Helicobacter pylori: characteristics, pathogenicity, detection methods and mode of transmission implicating foods and water. Int. J. Food Microbiol., 53: 95-104, 1999.

22. Versalovic, J.; Fox, J.G. Helicobacter. In: Murray, P.R.; Baron, E.J.; Pfaller, M.A.; Tenover, F.C.; Yolken, R.H. Manual of Clinical Microbiology. Washington: ASM Press, 1999, p.727-737.

23. West, A.P.; Millar, M.R.; Tompkins, D.S. Survival of Helicobacter pylori in water and saline. J. Clin. Pathol., 43: 609, 1990.

24. West, A.P.; Millar, M.R.; Tompkins, D.S. Effect of physical environment on survival of Helicobacter pylori. J. Clin. Pathol., 45: 228-231, 1992. 